\title{
Labor Migrations and Socio-Economic Indexes: Problems and Prospects for Russia
}

\author{
Pshenichnyi S.P. \\ Mukhametshin D.F. \\ Leukhin A.O. \\ Bichkov G.A.
}

Kazan Federal University, Institute of Management, Economics and Finance, Kazan, 420008, Russia

\section{Doi:10.5901/mjss.2015.v6n3p723}

\section{Abstract}

The article is devoted to analysis of the key socio-economic factors having impact on labor migration in the context of intercountry economic heterogeneity interrelations. The assessment of the Russian Federation position in labor market is given. The threats connected with labor migration for economy of Russia are allocated. The special attention is paid to recurrence of economic development and factors of the human capital formation. The importance of the state migration policy on formation of competitive advantages and structure of labor market, an adequate current situation is noted especially. Also in work the measures taken by the state and their influence on migratory processes are analyzed.

Keywords: labor migration, human capital, recurrence of economic development, migration policy, competitive advantages.

\section{Introduction}

Each economic system of the modern world has rather inconsistent and eclectic character, nevertheless, in each of these models it is possible to mark out characteristic features. Though, both the structure of employment and the labor market are limited to the system framework, but each system has formed and functions under the influence of various factors, such as: social and economic, demographic and institutional. Besides, the factors that are general for world economy have considerable impact on structure of employment and labor market. The level and dynamics of migratory processes, changes in structure of international trade, development of information technologies and innovations are universal factors. At the last decades a special attention was paid to the labor migration problem as in Russia, and abroad. At present time about 1,5 million migrants have the registered rights for implementation of work in Russia. Relevance, the importance and sharpness of a problem affected, the migration questions are taken on special control by the International Labour Organization, and the governments of the certain countries, including the President and the Government of the Russian Federation.

\section{Theoretical Analysis and Research Methods}

Labor migration as multidimensional process includes questions of the economic, social and political relations. Sociologists, in particular, actively investigate intensity of migratory streams, their demography, socialization possibilities of labor migrants in the Russian society. Economists discuss questions of structural changes in labor market, and also the dynamics of the overall economic efficiency connected with labor migrants inflow. Among the most significant factors that create inflow of a manpower to the country there are, on the one hand, steady lack of job demand in some spheres of activity at representatives of indigenous people, and on another - interest of receiving the benefits caused by higher quality of life. Besides, distinction in unemployment rate, specifics of formation of a manpower, including overpopulation and low labor productivity level, and also labor cost in the different countries has essential impact on migratory streams.

External labor migration promotes increasing of economic pressure to social system of the country. External labor migration processes includes not only inflow of foreign labor, but also such important aspect as departure from the country of the most qualified specialists who are the Russian citizens. The one reason of this situation is that in internal economy the workplaces allowing to realize the potential to this category of workers and to provide high quality of life for itself and the family are not created. On the other hand - an important factor is the aggressive involvement policy of the 
leading western states in relation to most talented and perspective experts. Especially brightly, this tendency is shown in the sphere of IT technologies and financial services. "Brain drain" from the most perspective spheres of economy, turns into decline of the human capital quality and impossibility to provide a sustainable development of territories. [3].

Researchers pay their attention to essential interrelation between two main types of migration - external and internal. Internal labor migration is connected with processes of an manpower inflow to regions in which the quality of life is better. The main reason of such situation is considerable differentiation of quality of life and lack of opportunities for employment in the region of residence [4].

Within the presented theoretical analysis, we showed the interrelation between conditions of social and economic development and migratory streams [9]. The analysis of these factors is especially important and allows to formulate reasonably strategy of development in the employment sphere. Besides, it is important to note that the problems of labor migration are interdisciplinarity. The specified circumstance reflects that we must use not only sociological, politological and economic methods, but to consider them as complementary resources for receiving complete result [11].

\section{Results}

According to researches, the structure of labor market depends on such indicators as labor productivity, the level of territory development, which is expressed through an indicator of gross domestic product, existence of workers with the necessary qualification, level of salaries. Development of Russian economy is characterized by labor productivity, which is lower than in the European countries, and at the same time by qualification of workers which is rather high [1]. Low labor productivity and higher level of salaries and social guarantees allows Russia to hold low unemployment rate. Now migratory appeal of the Russian Federation in comparison with other countries accepting migrants is low. The specified aspects promote migratory streams from the countries where the level and quality of life is lower. In the majority these countries are presented by the republics of the former Soviet Union (Fig.1).

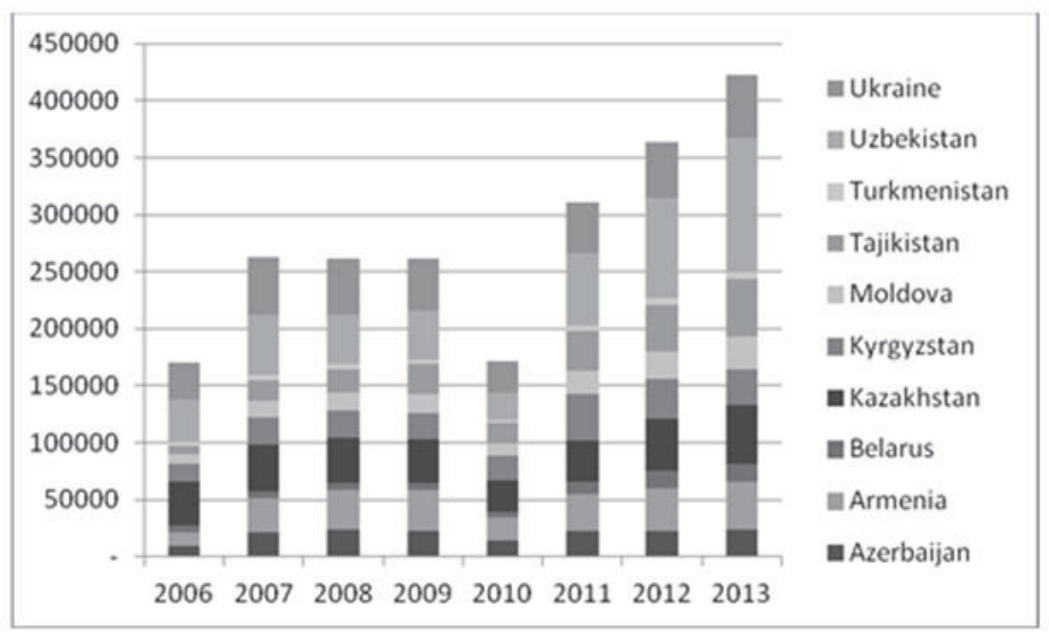

Figure 1. Citizens of the CIS, who have permission for work in the Russian Federation.

Low educational and vocational preparation levels, poor knowledge of Russian language are characteristics of new generations of migrants. [6]. Distinctive features of work of foreign citizens in the Russian Federation, is that they are occupied in branches, which rather steadily develop [8]. It should be noted that the greatest number of external labor migrants find the application in the sphere of construction and in the services branches. (Fig.2). 


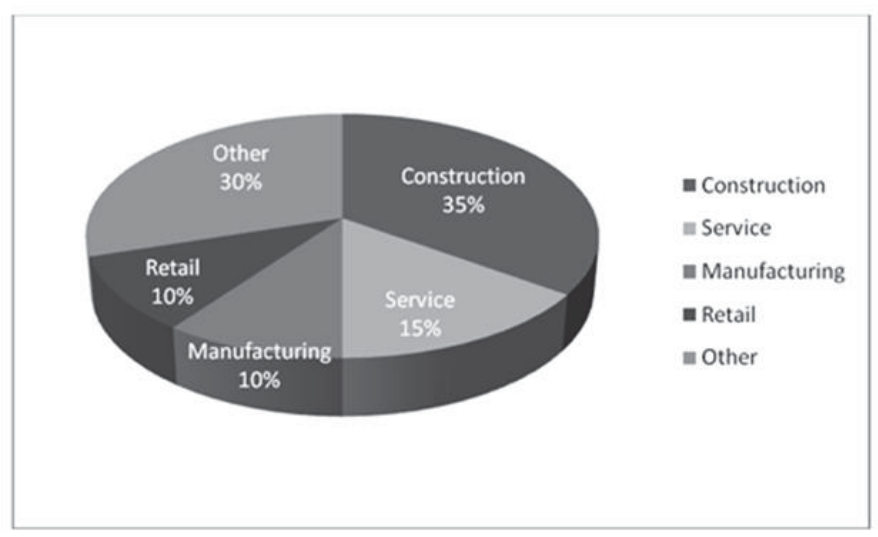

Figure 2. Branches of Russian economy where foreign citizens works.

Imperfection of the migratory system makes possible many illegal migrants. Annually in the Russian Federation is from 3 to 5 million foreign citizens, who works without official permission. The illegal migration feeding with labor shadow sector of economy is one of the main reasons that strengthen the negative attitude to migrants from part of indigenous people from the Russian Federation. Along with existence of entrance migration, emigration outflow from the country takes place also. According to official statistics, more than 3 million people emigrated from Russia since 1992. The domestic innovative sector has very serious problems with big outflow of experts from Russia [7].

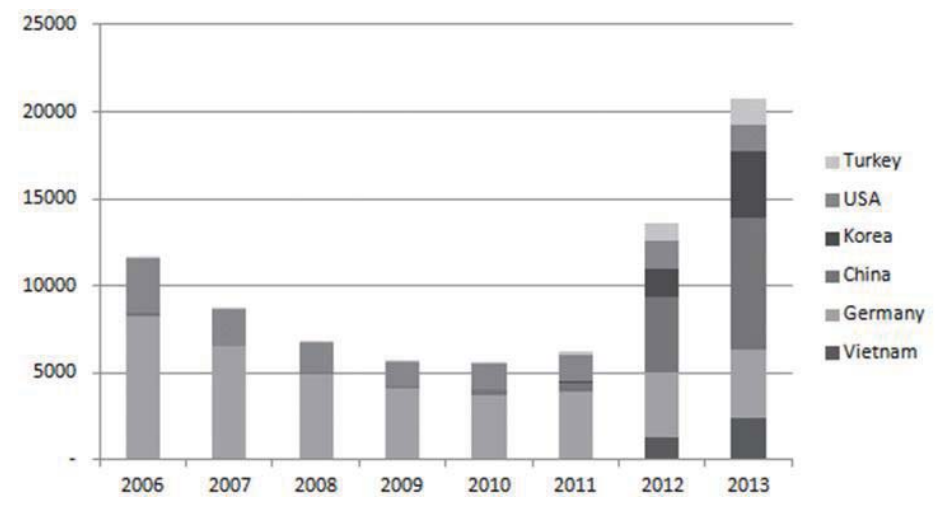

Figure 3. The most popular directions of migration from the Russian Federation.

Experts outflow from the country increase labor resources deficit and activate internal migration.

Table 1. Indicators of labor migration between federal districts of the Russian Federation in 2013

\begin{tabular}{|c|c|c|c|c|c|c|c|c|c|}
\hline \multirow{2}{*}{ 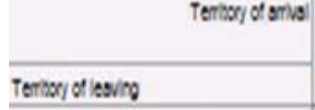 } & \multirow{2}{*}{$\begin{array}{l}\text { Russion } \\
\text { Fosoraton }\end{array}$} & \multicolumn{8}{|c|}{ To fosoral ositriots } \\
\hline & & Cenvel ossile: & Nortues: 0sye: & Soura osris: & Nore Covessign ostie: & Vogon five ossis: & Ungloss/: & sberanoszie: & Fe Ess: Osyil: \\
\hline Russion Fosoraton & 4014020 & в87า0 & 488851 & 376060 & 100108 & moss & 40484s & 681116 & 214848 \\
\hline \multicolumn{10}{|l|}{ From fostal olsovics } \\
\hline Cental 0sris: & 245149 & 667059 & 45875 & 3367 & 16529 & 4715 & 13953 & 15011 & 10060 \\
\hline Nornes: 0syict & 45606 & 55111 & 365331 & 165:1 & 6309 & 205:1 & 6737 & 7034 & 5332 \\
\hline Souh osvic: & 339008 & 49967 & 18559 & .212077 & 19185 & 13954 & 10559 & 9180 & 6277 \\
\hline Non Cojessisn osyict & 256981 & 33452 & 13331 & 32544 & 120091 & 6002 & 1303: & 5162 & 8657 \\
\hline Voga fives ossis: & 83assi & 94929 & 34873 & 1967 & 5196 & 617609 & 49343 & 10079 & 6435 \\
\hline Ura osrie: & 61004 & 26594 & 13725 & 18128 & 8408 & 46640 & 226519 & 17817 & 2817 \\
\hline Sbersnostis: & 633210 & 37370 & 19484 & 24063 & 4565 & 12923 & 21459 & 497538 & 15698 \\
\hline Fy Ess: Dsyis: & 253951 & 23538 & 16593 & 17075 & 242 & 6667 & 3781 & 12495 & 165360 \\
\hline
\end{tabular}


The centers of migrants gravity in Russia are the Moscow region, Moscow, St. Petersburg[5], as well as other economic centers with the diversified labor markets providing rather high level of a salary and possessing the developed infrastructure [10]. It causes deformations of labor market in other regions and reduces the level of economic security. Internal migration changes the population placement structure and accumulates uncontrollable deformation in economy.

The assessment of migratory problems leads to conclusion that most of them are consequences of inconsistency between the indicators reflecting the purposes of social and economic development and migration policy. An important condition of economic achievement, political integration, sustainable development and national security for Russia is the correction of migration policy. Experience of the countries with active migration policy, shows that migratory processes can accelerate social and economic development and provide welfare growth.

Joint efforts of representatives of the state, business and civil society allow making a solution of designated problems. The Conception of the Russian Federation migration policy of for the period till 2025 defined strategic migration policy priorities and mechanisms and became an important step in the sphere of migration[1]. Meanwhile, it is necessary to include other participants of economic activity in this process.

\section{Conclusion}

Within the conducted research, the following conclusions concerning influence of socio-economic factors on labor migration streams formation, were received. First of all, the increase of external migratory streams shifts in the long term from the sphere of "low-qualified specialists" to high-tech industries and poses serious threat of economic security of the country. This situation is complicated by the existence of mechanisms that recruit to the country labor migrants from foreign students [6]. The processes of creation new hi-tech workplaces for the population of the Russian Federation become one of the main requirements to national economy in the conditions of increase in migratory streams. This task is very difficult in conditions of the budget resources restriction caused by negative market situation [2]. Besides, the instruments of interdepartmental interaction that have been created can carry out regulation of migratory processes only by administrative decisions, thus economic mechanisms remain poorly involved. It is possible to draw a conclusion that Russia has essential vulnerability from external migratory streams and that development of new economic security preservation mechanisms is very important in the conditions of economy globalization.

\section{References}

Bagautdinova, N.G., Gafurov, I.R., Novenkova, A.Z. The transformation of region's economic area governed by the development of industrial region//World Applied Sciences Journal.Volume 25, Issue 7, 2013, pp. 1113-1117.

Bagautdinova, N.G., Safiullin, L.N., Minnahmetov, R.R. Institutionalization of firm environment in conditions of growing turbulence//Mediterranean Journal of Social Sciences.Volume 5, Issue 12, June 2014, pp. 55-58

Fakhrutdinova, E., Safina, L., Shigapova, D.,Yagudin, R. Legislative provision of the quality of working life in Russia// World Applied Sciences Journal 201327 (13), pp. 92-96

Gaisin, I.T., Biktimirov, N.M. Migration processes in the Republic of Tatarstan in the second half of the 20th and in the th early of 21st centuries: Ethnic and social aspects//Middle - East Journal of Scientific Research. Volume 20, Issue 12, 2014, pp. 1761-1766

Karasik, E., Yagudin, R., Leukhin, A.,Zagidullina, V. Improvement of social policy towards the disabled in the Russian Federation//Life Science Journal 201411 (6 SPEC. ISSUE), pp. 478-481

Fakhrutdinova, E., Karasik, E., Safina, L.,Miropol'skaya, N. The role of social protection in formation of quality of work life //World Applied Sciences Journal 201327 (13), pp. 77-81

Ryazantsev, S.V., Bozhenko, V.V. New approaches to managing labor migration under integration in Eurasec//Asian Social Science. Volume 10, pp. 195-201.

Fakhrutdinova, E., Kirshin, I., Kolesnikova, J.,Salyakhov, E. The influence of cross-country technological transfer on economic profit formation// Middle East Journal of Scientific Research 201317 (12), pp. 1632-1634

Safiullin, L.N., Gafurov, I.R., Shaidullin, R.N., Safiullin, N.Z Socio-economic development of the region and its historical and cultural heritage.//Life Science Journal.Volume 11, Issue 6 SPEC. ISSUE, 2014, pp. 400-404.

Safiullin, M.R., El'shin, L.A., Shakirova, A.I. Evaluation of business and economic activity as a short-term forecasting tool//Herald of the Russian Academy of Sciences.Volume 82, Issue 4, pp. 290-294. 